\title{
THE IMPROVEMENT OF THE STABILITY PROBLEM OF RESHA GENERATION PLANT IN JORDAN
}

\author{
Mahmoud S. Awad ${ }^{1}$, Anwar Al-Mofleh ${ }^{1}$ \\ ${ }^{1}$ Faculty of engineering Technology/ Al-Balqa' Applied University \\ Amman, Jordan Amman, P.O.Box (15008), marka ashamalia \\ Tel (+96277387901) Email: dr_awad_m@yahoo.com, \\ anwaralmofleh@yahoo.com
}

\section{ABSTRACT}

This study, discuss the stability problem of Resha generation plant. The length of the transmission line which connect Resha with Haranah station, decrease the power transferred capacity that increase the risk of transient disturbance on the system, especially when the generators loaded at full load. Beside that several solutions were suggest in order to improve system stability and raise the capacity of transmitted power.

\section{General Terms}

Power Stability

\section{Indexing terms}

Stability, generation, energy sector, electricity

\section{Academic Discipline and Sub-Disciplines}

Provide examples of relevant academic disciplines for this journal: E.g., History; Education; Sociology; Psychology; Cultural Studies;

\section{SUBJECT CLASSIFICATION}

Engineering

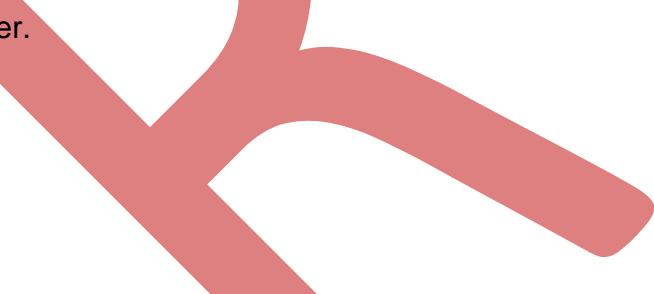




\section{INTRODUCTION}

Energy and electricity in Jordan The year 2011 is considered the most difficult year for the energy and electricity sector in Jordan due to the current political conditions in the region which in turn mainly contributed to increasing challenges facing this sector since Jordan imports more than $(97 \%)$ of its oil needs and that about $(80 \%)$ of electric power generated in Jordan depends on the natural gas imported from Egypt which in turn has witnessed a great reversion this year, where daily supply rate has amounted to about (92) million cubic feet, while the regular need of Jordan is about (255) million cubic feet. This required operating power plants using heavy fuel and diesel to meet electric power demand. In spite of these challenges, energy sector in Jordan has been able to continue its achievements and keep pace with recent and rapid developments by meeting the growing demand for different energy sources in general and electric power in particular. However, it has become urgent to find the appropriate solutions to face this fact in the light of the comprehensive national strategy of energy sector and the future vision derived from it which includes the need to utilize local energy sources depending on oil shale, uranium, use nuclear energy instead of oil to generate electric power, increase renewable energy sources projects, reinforce regional interconnection projects, and create opportunities for the private sector to invest in infrastructure projects of energy sector. This strategy seeks to increase reliance on local and renewable energy from (4\%) in the current year to (13\%) in 2016, then to (39\%) in 2020 [1-5].

\section{Power Sector Organization}

As shown in Figure 1 the power sector in Jordan is consisting from the following:

\subsection{National Electric Power Company (NEPCO)}

National Electric Power Company is considered to become the natural and legal successor to Jordan Electricity Authority.

NEPCO's activities include the following:

- To plan, construct, develop, operate and maintain the power system

- To purchase electrical energy from various sources and sell it to distribution companies and large consumers (Single Buyer)

- To procure natural gas for power stations.

- To maintain a safe and economic operation of the power system.

- To import and export of electric power.

\subsection{Central Electricity Generating Company (CEGCO)}

The operation of the Central Electricity Generating Company (CEGCO) started on 1/1/1999 as a public company stemming from the governmental policies related to restructuring the electrical sector. On September 20 th, 2007 CEGCO was privatized. CEGCO currently owns about $1600 \mathrm{MW}$ of generation capacity and its activities include power generation, operation and maintenance of their power plants.

\subsection{Samra Electric Power Generation Company (SEPGCO)}

Samra Electric Power Generating Company (SEPGCO) was established and owned by the Jordan government in August 27th, 2003. Expanding Samra Power Plant (third phase) project was completed, by adding two gas turbines with capacity of (142) MW for each, operated by simple cycle system where the total generating capacity of the plant has become about (884) MW. It is expected to add a steam turbine with capacity of (142) MW by 2015 where the total generating capacity of the plant will become about (1026) MW.

2.4 Independent power provider (IPP)

A $300 \mathrm{MW}$ independent power provider (IPP) of Amman east power plant was completed in 2009. The next $300 \mathrm{MW}$ stage is expected to be operated in 2010. A second 380 MW IPP will be established at AL-Qatranah Electrical Power Company.

\subsection{Jordan Electric Power Company (JEPCO)}

Jordan Electric Company (JEPCO) was established by the private sector in 1938. JEPCO is an electricity distribution company with a concession that covers the central part of Jordan. The concession gives the rights to JEPCO to distribute electricity in an area that includes major cities such as Amman, Zarqa, Salt and Madaba.

2.6 Irbid District Electricity Company (IDECO)

Irbid District electricity Company (IDECO) was established in 1957. It is operating under concession agreement and electricity license which granted IDECO the exclusive right to distribute, and supply electricity in the northern region of Jordan, which include Irbid, Jarash, Ajloun and parts of Balqa district.

\subsection{Electricity Distribution Company (EDCO)}

Electricity Distribution Company (EDCO) was established in 1998 as a public shareholding company. The company operates under concession law which granted EDCO the exclusive right to distribute and supply electricity in the southern region of Jordan. EDCO was privatized in 2008 by selling 100 percent of its shares to Kingdome Electricity Company (KEC) which is owned by Dubai Capital Company. 


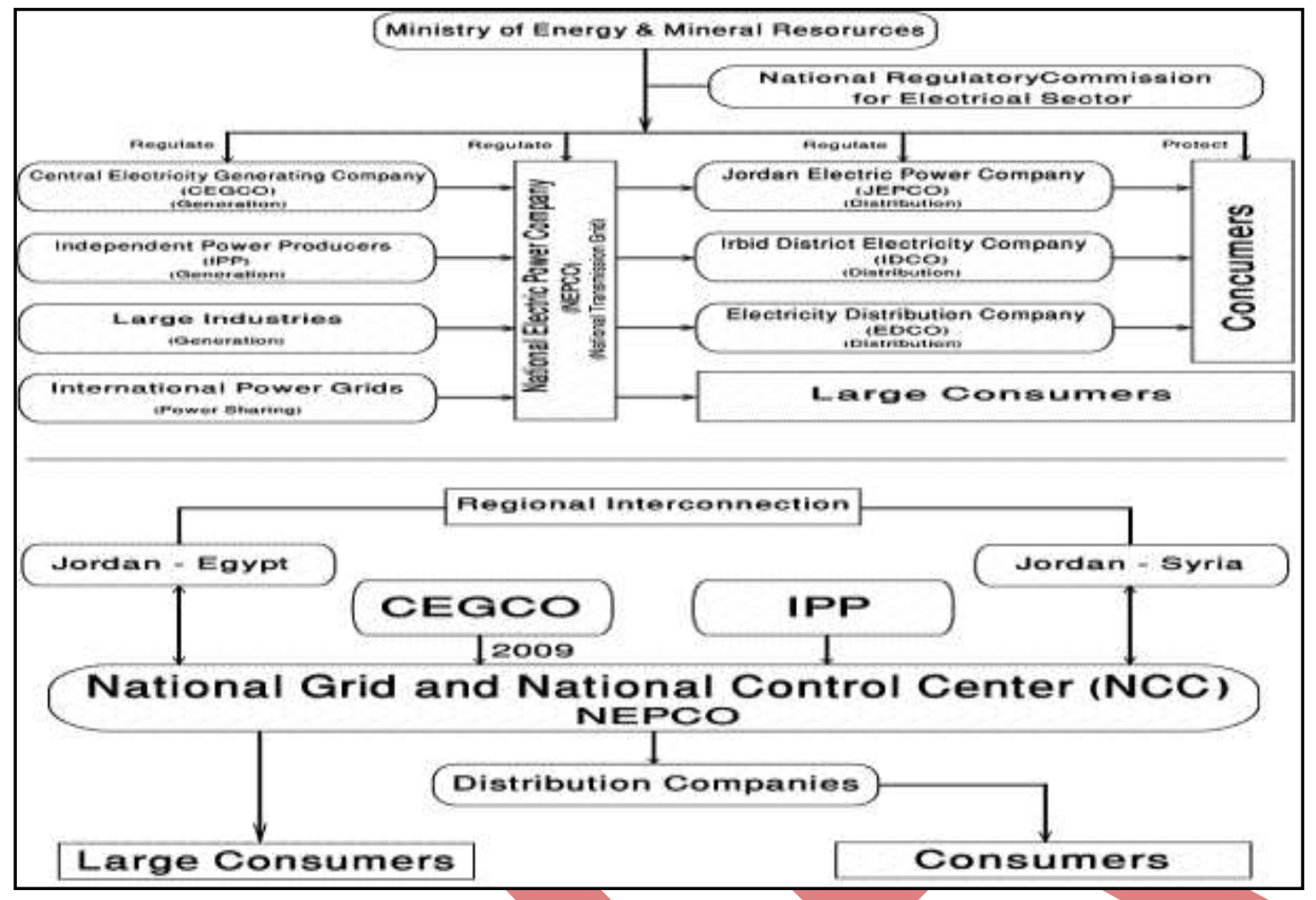

Fig 1: A plan explain Jordanian power sector organization

\section{Electric power statistics}

The Table 1 below shows the peak load and electricity energy consumption in Jordan for the period 2008-2011. The Table shows also the installed capacity and energy generation for the same period. The total peak load in the kingdom reached to $2680 \mathrm{mw}$ at 2011 compared to $2560 \mathrm{mw}$ in 2010 with a growth of $4.7 \%$. The generating and imported energy in the Kingdom amounted to $16385 \mathrm{GWh}$ in 2011 with an annual growth rate of $6.1 \%$. The total generated energy in the kingdom amounted to (14647) GWh in 2011 with an annual growth rate of negative $(0.9 \%)$. Electricity consumption in the Kingdom amounted to $13534.9 \mathrm{GWh}$ in the year 2011 against $12857.4 \mathrm{GWh}$ in 2010 , with an annual increase of $5.3 \%$. The average electricity consumption capita was $2167 \mathrm{KWh}$ in 2011 against $2103 \mathrm{KWh}$ in 2010 with a growth rate of $3.0 \%$. As shown in Figure 2and 3 respectively [6-10].

Table 1: peak load and electricity energy consumption in Jordan

\begin{tabular}{|c|c|c|c|c|c|}
\hline Year & \multicolumn{2}{|c|}{$\begin{array}{c}\text { Peak Load } \\
(\mathrm{MW})\end{array}$} & $\begin{array}{c}\text { Electrical energy } \\
\text { consumption } \\
\text { (GWH) }\end{array}$ & $\begin{array}{c}\text { installed capacity } \\
\text { (MVA) }\end{array}$ & $\begin{array}{c}\text { Energy } \\
\text { generation } \\
\text { GWH/YEAR }\end{array}$ \\
\cline { 2 - 3 } & Generated & Sent out & 11508.9 & 2560 & 13838 \\
\hline 2008 & 2260 & 2150 & 11956.3 & 2560 & 14272 \\
\hline 2009 & 2320 & 2220 & 12857.4 & 3760 & 14777 \\
\hline 2010 & 2670 & 2520 & 13834.9 & 3760 & 14647 \\
\hline 2011 & 2790 & 2680 & & & \\
\hline
\end{tabular}




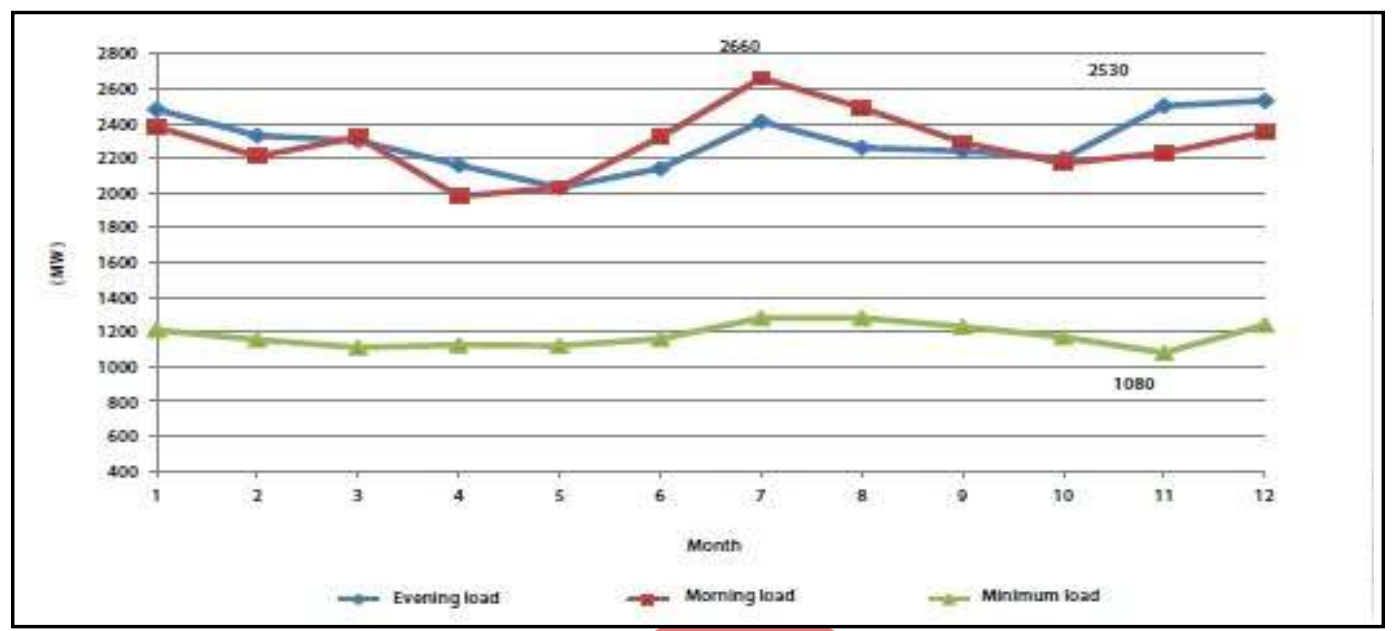

Fig 2: Monthly Evening, Morning \& Minimum Loads in 2011

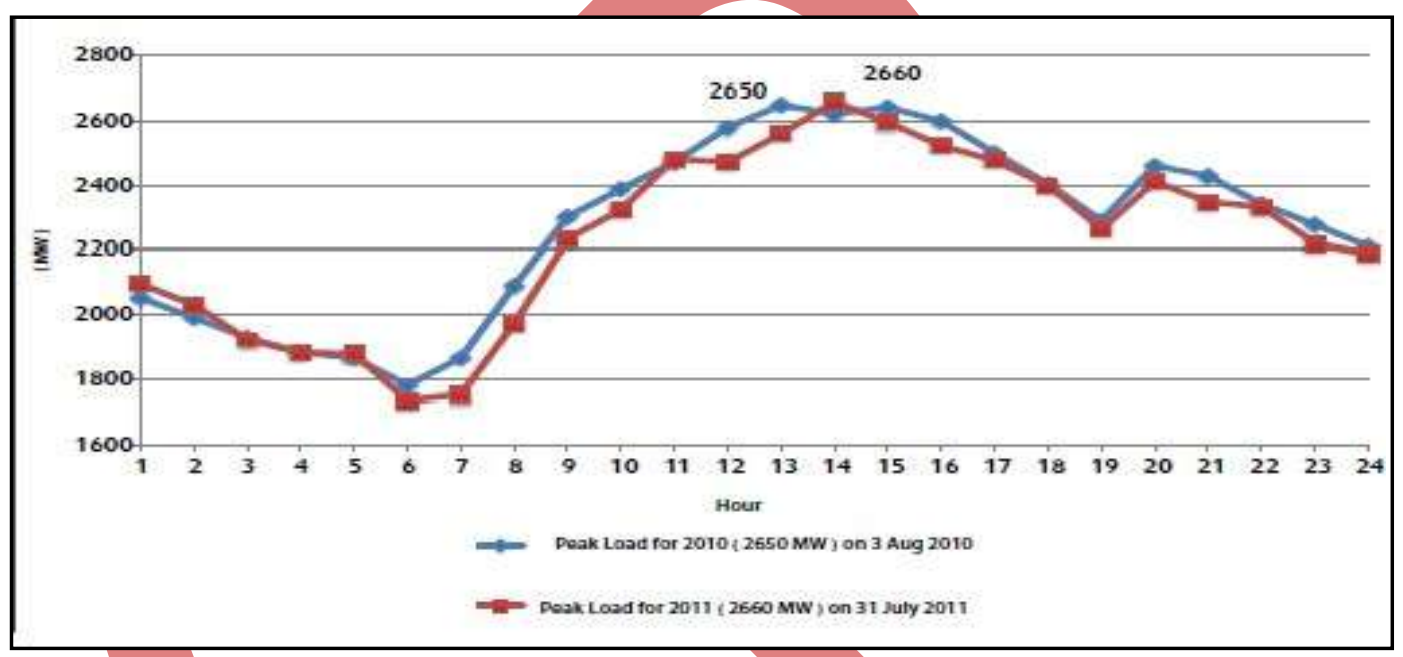

Fig 3: Electrical System Peak Load for Years 2010 \& 2011

\section{Description of Resha Gas Power Station}

Resha power plant is one of the central electricity generation company (CEGCO) station, The power station began producing electric energy by burning natural gas since 1989. The generating capacity in the station amounted to $150 \mathrm{MW}$, it's used Natural gas and diesel oil. It's located in the eastern region of Jordan, approximately $350 \mathrm{~km}$ from Amman and 1 $\mathrm{km}$ from the border with Iraq. Resha power plant comprises five simple cycle generating units, each nominally rated at 30 MW gross, each generating $11 \mathrm{KV}$, which will increase the voltage to $132 \mathrm{kV}$ by transformer stations to raise the voltage. All details of these generators are in Table 2.

Table 2: Description of Resha Gas Power Station

\begin{tabular}{|c|c|c|c|c|c|c|}
\hline \multirow{2}{*}{ NAME } & GEN TYPE & \multicolumn{3}{|c|}{ RATING } & Xd & H \\
\cline { 3 - 5 } & & KV & KVA & KW & $(\mathbf{p . u})$ & (MWs/MVA) \\
\hline RSHA GT1 & G.T/GENROU & 11 & 44.7 & 30 & 0.338 & 5.35 \\
\hline RSHA GT2 & G.T/GENROU & 11 & 44.7 & 30 & 0.338 & 5.35 \\
\hline RSHA GT3 & G.T/GENROU & 11 & 33 & 30 & 0.195 & 7.26 \\
\hline RSHA GT4 & G.T/GENROU & 11 & 37.5 & 30 & 0.183 & 5.35 \\
\hline RSHA GT5 & G.T/GENROU & 11 & 45 & 30 & 0.183 & 5.35 \\
\hline
\end{tabular}


The total generated energy in Resha power plant amounted to $476.71 \mathrm{GWH}$ in 2011. In the power plant turbine capacity of $30 \mathrm{MW}$ and thus provide Jordan with $15 \%$ of the total demand for electric power, which it's associated with power distribution station in Aharana by two circuits, One linked to the Haraneh station by length $283 \mathrm{~km}$. Also along the other circuit, there are two other stations between Resha plant and Haraneh station. There is Rwiashed station which located 71 $\mathrm{km}$ away from Resha station. And Safawi station which located $116 \mathrm{~km}$ away from Rwaished. The natural gas is the main fuel used. Gas resources varied between Egyptian gas and from production wells $\mathrm{RH}-3$ and $\mathrm{RH}-6$. At the gas plant the well stream is treated to produce gas suitable for use as turbine fuel for the 60MW power generation. The treatment includes pressure reduction, liquid separation and glycol dehydrations. The treated gas is then transported to the power station situated $3.5 \mathrm{~km}$ from the gas plant, via a $10 \mathrm{inch}$ pipeline. With expectations to increase gas production from Resha gas wells, an additional generator unit is planned to be added to increase the total capacity to $160 \mathrm{MW}$.

\section{- The Resha stability problem}

Resha power plant, experienced difficulties due to transient instability. When the generated power reaches certain limits, stable operation would become of greater importance. This system undoubtedly would present problems in transient instability due to the length of the transmission line. Because of high magnitude of line reactance $(x)$ between the sending part and receiving end. A principal object of the study was to determine maximum allowable power which Resha plant can generate with the condition keeping stability even in occurrence of transient disturbance and then study several solutions improve the stability of plant's generators. The solution will consider in this study are [11, 12]:

1. adding new parallel transmission line.

2. adding new line and disconnect generating unit.

3. adding series capacitors.

4. change clearing time.

5. adding reactors.

This study involve the rest of Jordanian system which is effected by disturbances occur on Resha plant. So it include great masses data and calculations which it was impossible to complete this study without aid of computer program, Therefore, all study and results derived obtained with the help of DIgSILENT PowerFactory@2 . In the foregoing discussion of the solution of Resha power plant, it was assumed that:

1. The mechanical power input to each machine remains constant during the entire period of the swing curve computation.

2. Damping power is negligible.

3. The mechanical rotor angle of each machine coincides with $\delta$, the electrical phase angle of the transient internal voltage.

4. Reactive power distribution according to dispatched active power.

For best results, the study assume the worst disturbance could the Resha plant experience, which it is three phase short circuit fault locate on the long 132kv transmission line near the Resha plant's main 132kv bus bar. Distance relay detect the three phase fault on transmission line. And clearing it by opens circuit breakers and gets it out of service. The standard clearing of distance relay generally between $(80-120) \mathrm{ms}$. In this study $120 \mathrm{~ms}$ clearing time is used to assume the worst case.

\section{- Swing curves}

In determining the maximum power can be generated without losing stability several runs must be made. The first run was made at $80 \mathrm{MW}$. If the system is stable, another run was made at new power level. This procedure kept until the run showed the system to be unstable. At this point of study, solution which improves stability must be added each solution separately in each case, and new runs are made until reach the new generated power limit. Each solution was added individually to study its effect separately from other cases. It worth mentioning that the run assume a steady state period for $1^{\text {st }}$ at $\mathrm{t}=1$, three phase short circuit happened and cleared after $120 \mathrm{~ms}$ by getting transmission line out of service. The whole period of simulation is $20 \mathrm{~s}$. 
Council for Innovative Research www.cirworld.com
International Journal of Computers \& Technology

Volume 4 No. 2, March-April, 2013, ISSN 2277-3061

Case1: Normal condition, 120 ms clearing time, three phase short circuit fault on $132 \mathrm{KV}$ transmission line.

In the first run the total generated power is $80 \mathrm{MW}$, distributed on four generators, $20 \mathrm{MW}$ for each as shown in Figure 4. The simulation show that when a three phase short circuit fault occurred on the transmission line at $t=1 \mathrm{~s}$ and cleared after $120 \mathrm{~ms}$, the swing curve in Figure 5, shows that the system stay stable and the oscillation damped after short period. So anther run was made at $100 \mathrm{MW}$. The second run at $100 \mathrm{MW}$ presented in Figure 6 , shows that the system still stable.

Another run at $105 \mathrm{MW}$ was executed. The swing curve in Figure 3 shows that the system is stable. But it is obvious that the system couldn't back to steady state fast enough. The oscillation is higher than in the previous cases. Next the value was raised up to $110 \mathrm{MW}$ the swing curve display that stability is lost. From speed curve in Figure 7 , it can be seen that the rotor accelerated rapidly and out of step.
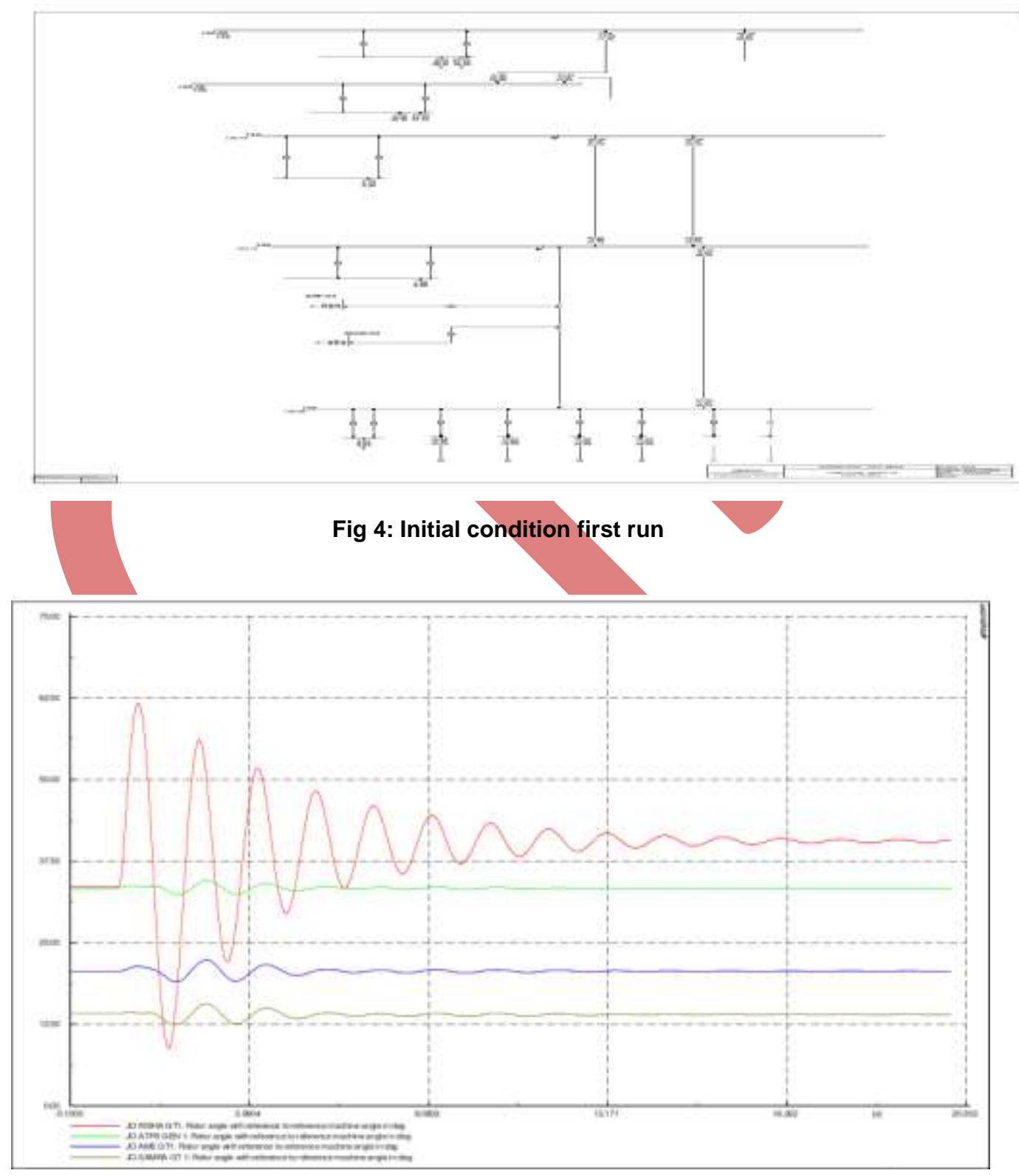

Fig 5: the swing curve 


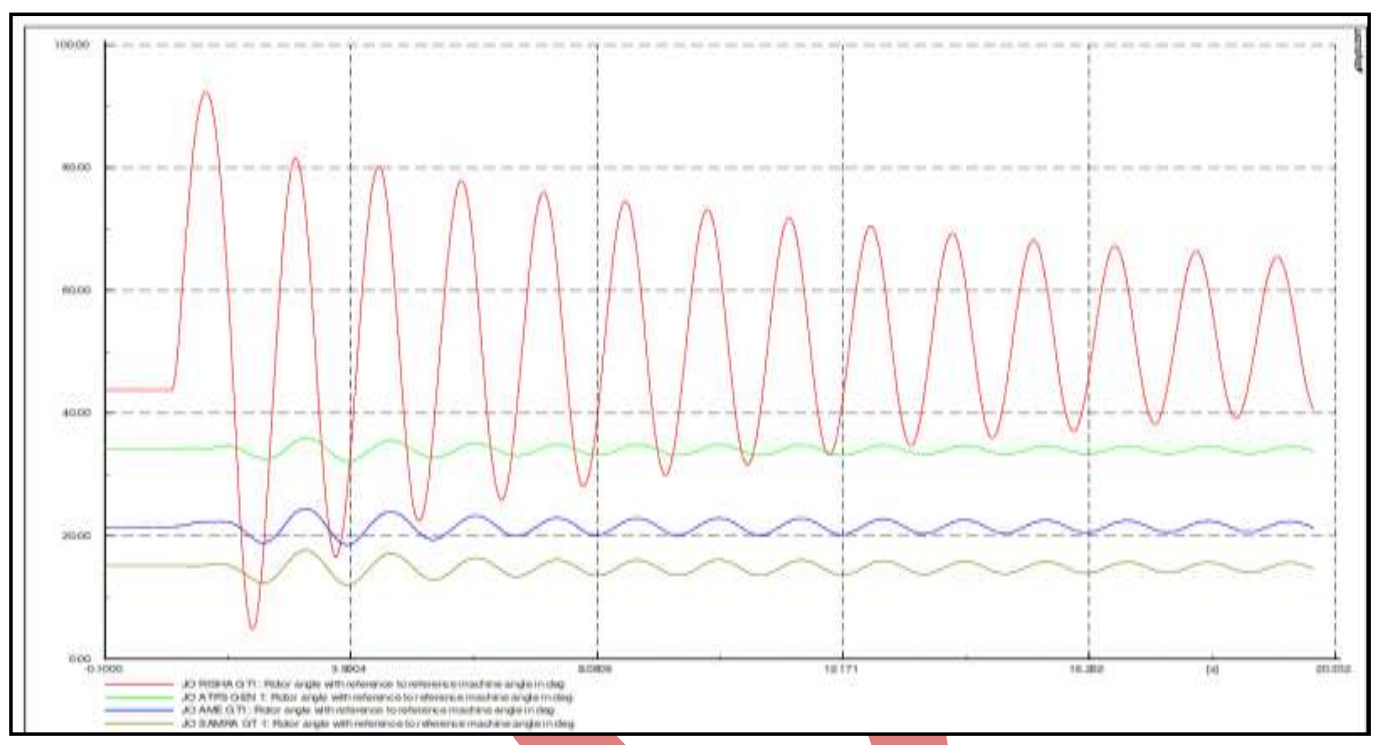

Fig 6: the swing curve second run

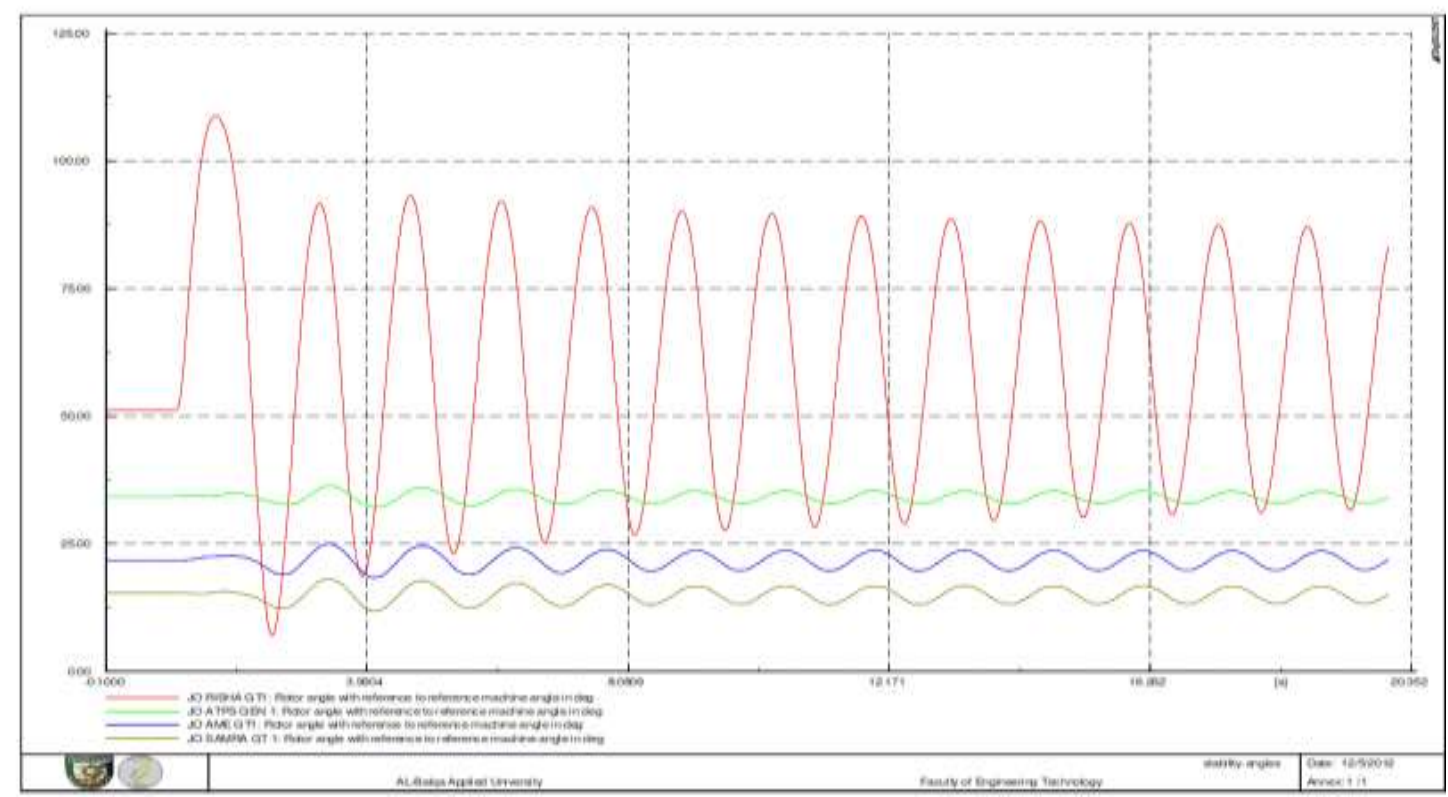

Fig 7: speed curve

Case 2: one unit drop, $120 \mathrm{~ms}$ clearing time, three phase short circuit fault on $132 \mathrm{KV}$ transmission line.

In this case, one generation unit was dropped, In addition to switch out transmission line. Technically speaking, generator tripping reduces the kinetic energy and consequently decreasing the power transfer among the critical intermediates in the transmission network. Swing curve Figure 8 at normal condition show the system was unstable when it loaded at 110MW. when it run at the same load condition and three phase short circuit fault occurred on the transmission line at $\mathrm{t}=1 \mathrm{~s}$ and cleared after $120 \mathrm{~ms}$, is explained by a decrease in the value of power. It is clearly at Figure 9 , the stability is missing, it's mean this method, dropping one unit, is suitable until load equal to $130 \mathrm{MW}$. 
Council for Innovative Research www.cirworld.com
International Journal of Computers \& Technology

Volume 4 No. 2, March-April, 2013, ISSN 2277-3061

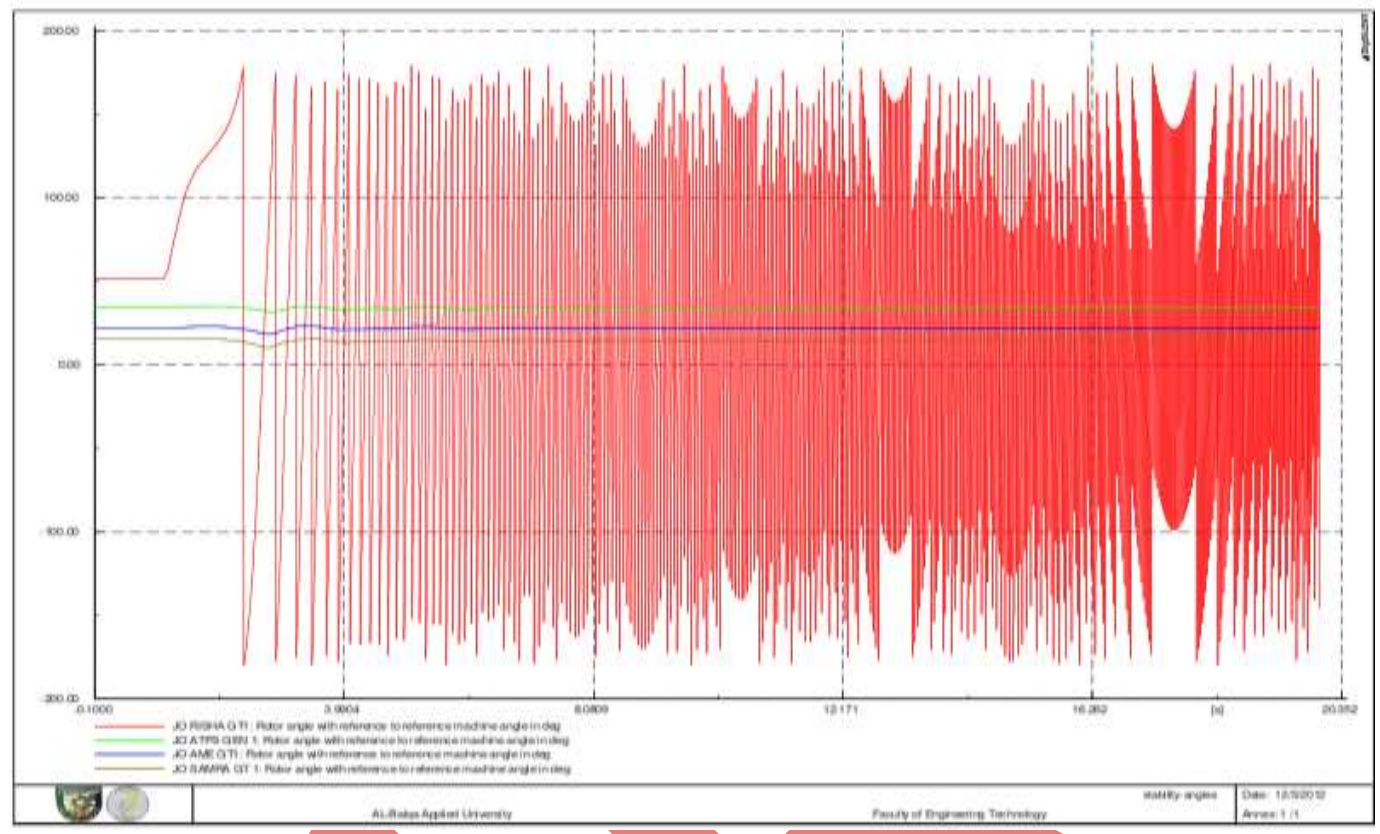

Fig 8: Swing at normal condition

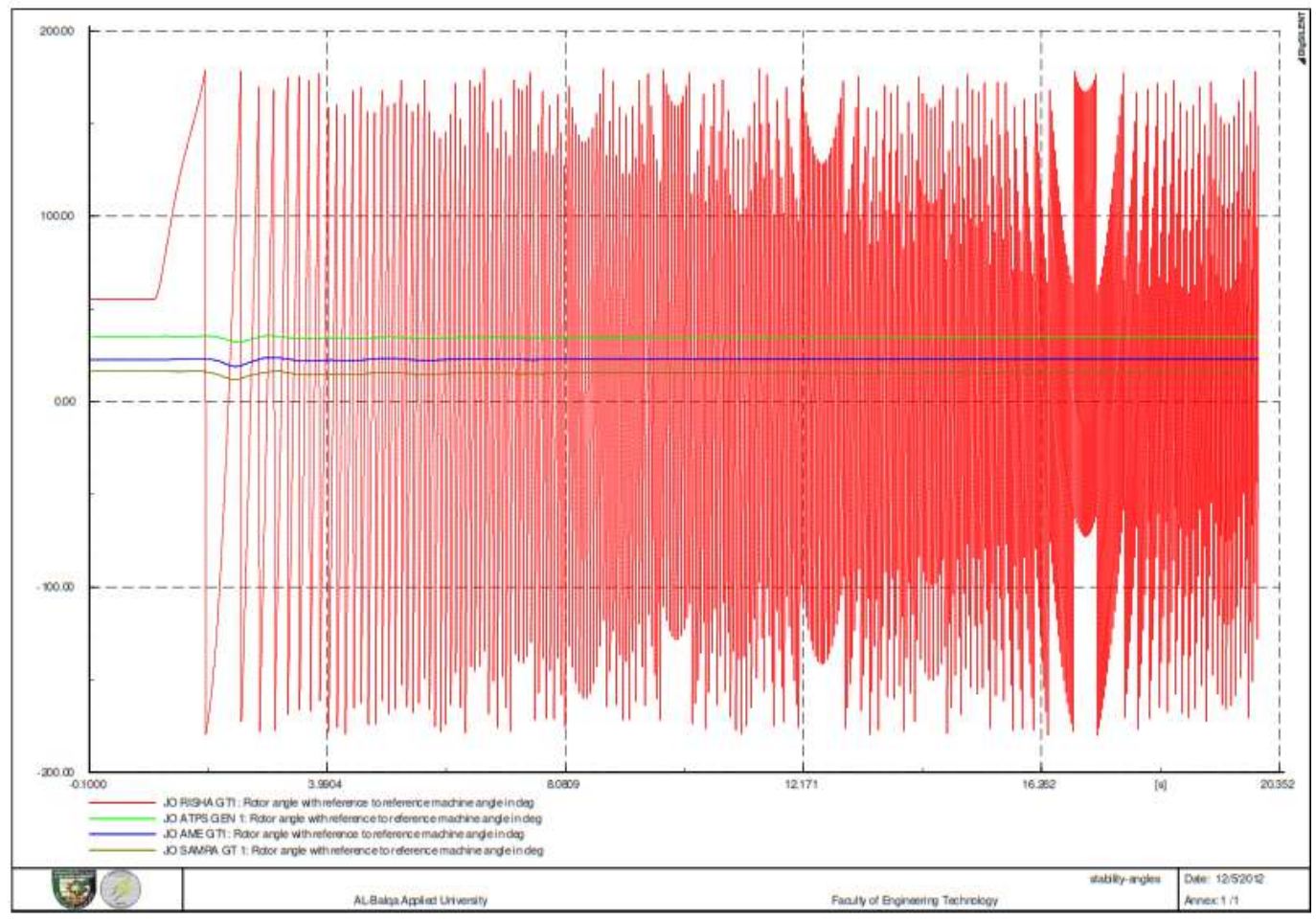

Fig 9: Angle curve.

\section{Conclusion}

The problem that we are concerned is the stability in Resha, if a disturbance occurs. The length of the transmission line between Resha station and Haraneh station enhance this problem, which reduces the power transmitted capacity and 
Council for Innovative Research www.cirworld.com
International Journal of Computers \& Technology

Volume 4 No. 2, March-April, 2013, ISSN 2277-3061

weaken the stability. The aim of the study is to determine the power limits could be transmitted between Resha station and Haraneh station, taking into consideration maintaining stability even if a three phase short circuit fault occur. Improvements which can be added to the system were proposed it in order to raise stability. Primarily, case 1 was executed without additions; generating units were loaded at $80 \mathrm{MW}$ and raised till reach instability state at $110 \mathrm{MW}$. The following case, case 4 , one generation unit was dropped at the same time of fault cleared. This procedure raise stability limit to 130MW.

\section{REFERENCES}

[1] Ministry of Energy and Mineral Resources Annual Reports

[2] Jaber, J.O., Mohsen, M.S., Probert, S.D., Alees, M.,( 2001) Future electricity demands and green house-gas emissions in Jordan. Applied Energy 69 (1), 1-18.

[3] Tamimi A, O'Jailat S(1996) Analysis of electrical energy generation and consumption in Jordan. Fuel Energy Abstr 1996; 37:29-35.

[4] World Energy Council (WEC). WEC member countries' national energy data. London, UK: World Energy Council; 2005.

[5] Ministry of Energy and Mineral Resources (MEMR). Annual report 2006. Amman, Jordan: Ministry of Energy and Mineral Resources; 2007.

[6] National Electricity Power Company (NEPCO). Annual report 2006. Amman, Jordan: National Electricity Power Company; 2007.

[7] Electricity Regularity Commission (ERC) website http://www.erc.gov.jo/Arabic/Pages/default.aspx

[8] National Electric Power Company (NEPCO) website, http://www.nepco.com.jo

[9] Jordanian Electric Power Company (JEPCO) website, http://www.jepco.com.jo/en

[10] Central Electricity Generating Company (CEGCO) website, http://www.cegco.com.jo/?q=en

[11] Farmer, Richard G(2001) Power System Dynamics and Stability" The Electric Power Engineering Handbook, Ed. L.L. Grigsby, Boca Raton: CRC Press LLC,2001

[12] Mostafa Eidiani, ,Mohammad Ebrahimean Baydokhty, Mahdi Ghamati, and Hossein Zeynal (2011) Transient Stability Improvement Using an Efficient Generator Tripping Scheme(2011), Canadian Journal on Electrical and Electronics Engineering Vol. 2, No. 7

\section{Author' biography with Photo}
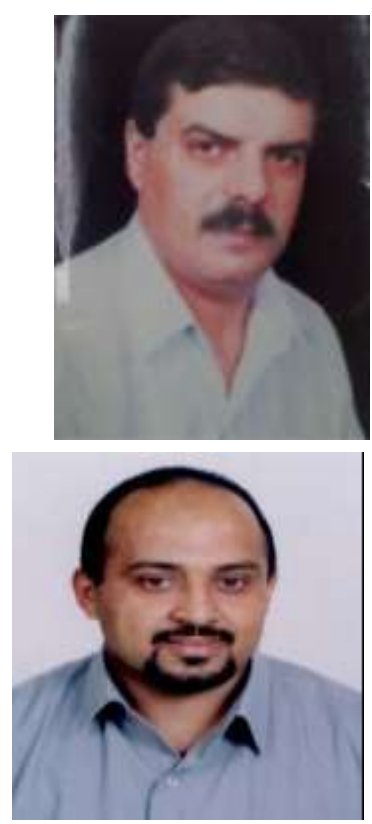

Mahmoud Awad: received his Master Degree in Electrical Networks and Systems, (1990).from Kiev Institute of Engineering (Ukraine). And the Ph.D. in Engineering Sciences (1994) Electrical Engineering / Power" Kiev Institute of Engineering (Ukraine). He is currently promoted the Associate professor with Department of electrical engineering Faculty of Engineering Technology, Al-Balqa' Applied University, Al-Salt, Jordan. His research interests include solar energy, renewable energy, energy efficiency and protection.

Anwar Al-Mofleh recived his B.Sc and MSc from Byelorussian Polytechnic academy in 1993.He is currently working as lecturer in Al-Balqa Applied University in Jordan and as candidate for PhD, at the fields of power and energy efficiency . E-mail address: anwaralmofleh@yahoo.com, Tel (+962779430087). 